\title{
Konsep ABG (Academic-Business-Government) dalam Rencana Sistem Industri Berbasis Potensi Daerah Kabupaten Sleman dan Gunung Kidul
}

\author{
Muhammad Prasanto Bimantio $^{1 *}$, Alva Edy Tontowi ${ }^{2}$ \\ ${ }^{1}$ Magister Teknik Sistem, Fakultas Teknik, Universitas Gadjah Mada \\ Jl. Teknika Utara No. 3 Barek, Yogyakarta, Indonesia 55281 \\ ${ }^{2}$ Departemen Teknik Mesin dan Industri, Fakultas Teknik, Universitas Gadjah Mada \\ Jl. Grafika No. 2, Yogyakarta, Indonesia 55281
}

\begin{abstract}
Abstrak
Daerah Istimewa Yogyakarta (DIY) mempunyai potensi industri yang cukup tinggi, baik industri kecil, menengah, maupun besar. Namun daya saing produk industri pengolahan di DIY rendah karena beberapa faktor, yakni masih lemahnya keterkaitan antar industri, keterbatasan produksi barang setengah jadi dan komponen di dalam negeri, keterbatasan industri berteknologi tinggi, kesenjangan kemampuan ekonomi antardaerah, serta ketergantungan ekspor pada beberapa komoditas tertentu. Penelitian ini bertujuan untuk membuat rancangan konsep kawasan industri berbasis potensi daerah (Domestic Based Industry/ DBI) menggunakan pendekatan sinergi Academic-Business-Government (ABG). Pendekatan ini dilakukan dengan fokus pada pemanfaatan bahan baku, sumber daya manusia, dan pemenuhan permintaan pasar lokal. Hasil kajian ini menghasilkan tiga konsep kawasan DBI yang diusulkan: (i) pengolahan produk turunan salak pondoh di Turi Sleman, (ii) pengolahan zeolit di Gedangsari Gunungkidul, dan (iii) pengolahan limbah produk biogas di Cangkringan Sleman. Ketiga konsep kawasan industri pengolahan tersebut saling terkait dan akan membentuk jejaring yang terintegrasi mulai dari bahan baku hingga produk, baik dengan industri rancangan baru maupun dengan industri yang sudah ada.
\end{abstract}

Kata kunci: kawasan industry berbasis potensi daerah; domestic based industry; ABG; salak pondoh; zeolit, biogas

\begin{abstract}
[Title: ABG (Academic-Business-Government) Concept for Planning Industrial System Based on Local Resources in Sleman and Gunungkidul Region]Yogyakarta Special Region (DIY) has an enormous industry potential, either small, medium, or large industries. However, the weakness of inter-industry linkages the limited production of intermediate goods and components in the country, the limitations of high-tech industries, the disparity of inter-regional economic capability, and export dependence on certain commodities make the competitiveness of the processing industry products in DIY lower. This paper presents a design of Domestic Based Industry (DBI) using the academic-business-government $(A B G)$ synergy approach. It focuses on the utilization of raw materials, human resources, and the fulfillment of local market demand. This research proposes three concepts of DBI areas: (i) processing of salak pondoh's derivative products in Turi Sleman, (ii) zeolite processing at Gedangsari Gunungkidul, (iii) processing of biogas product waste in Cangkringan Sleman. Those three concepts are interconnected to each other and will perform an integrated network of materials, ranging from raw materials to products, both with new design industries and with existing industries.
\end{abstract}

Keywords: domestic based industry; ABG; salacca pondoh; zeolite; biogas

\section{Metode Penelitian}

Daerah Istimewa Yogyakarta (DIY) mempunyai

\footnotetext{
${ }^{*}$ Penulis Korespondensi.

E-mail: bimantiomp@gmail.com
}

doi:10.14710/teknik.v38n2.15797 potensi industri yang cukup tinggi, baik industri kecil, menengah maupun besar. Sektor industri di DIY setiap tahun menunjukkan peningkatan baik dalam hal penyerapan tenaga kerja, investasi maupun nilai produksi. Lima cabang industri yang ada di DIY yaitu: industri pangan, industri sandang dan kulit, industri kimia dan bahan bangunan, industri logam dan eletronika serta 


\section{Teknik, 37 (2), 2017, 89}

industri kerajinan (Sarengat et al., 2015). Struktur industri pengolahan di DIY, berdasarkan hasil Sensus Ekonomi, didominasi oleh usaha industri berskala mikro dan kecil, sementara industri yang berskala menengah dan besar populasinya kecil (Badan Pusat Statistik Daerah Istimewa Yogyakarta, 2015).

Bidang industri ini merupakan salah satu penyumbang pendapatan daerah DIY. Perkembangan nilai Produk Domestik Regional Bruto (PDRB) DIY dalam beberapa tahun terakhir menunjukkan pola yang semakin meningkat. Atas Dasar Harga Berlaku (ADHB), PDRB meningkat dari Rp 64,7 triliun di tahun 2010 menjadi Rp 101,4 triliun di tahun 2015. Atas Dasar Harga Konstan (ADHK) tahun 2010, PDRB meningkat dari Rp 64,7 triliun di tahun 2010 menjadi Rp 83,5 triliun di tahun 2015. Selama periode 2010-2015, kinerja perekonomian DIY yang diukur dari pertumbuhan ekonomi mampu tumbuh rata-rata 5,2 persen per tahun. Meskipun demikian bila dibandingkan dengan daerah lain, peringkat PDRB DIY ADHB tahun 2015 berada di peringkat ke-22 secara nasional setelah Provinsi NTB dan sebelum Provinsi Kalimantan Tengah. Jika dibandingkan dengan lima provinsi lainnya di Pulau Jawa, nilai PDRB DIY ADHB tahun 2015 berada di posisi yang terendah (Badan Pusat Statistik Daerah Istimewa Yogyakarta, 2016).

Terkait dengan hal tersebut, pemerintah Provinsi DIY telah melakukan penjabaran analisis untuk sektor industri. Pemerintah DIY membuat kebijakan pembangunan sektor industri, dimana pembangunan bukan hanya membangun pabrik dan memasarkan hasil produksinya namun juga membangun sistem yang memungkinkan struktur ekonomi masyarakat setempat untuk berkembang secara mandiri.

Salah satu tantangan yang dihadapi industri nasional saat ini adalah daya saing yang rendah di pasar internasional. Faktor yang menyebabkan rendahnya daya saing tersebut antara lain adanya peningkatan biaya energi, tingginya biaya ekonomi, serta belum memadainya layanan birokrasi. Tantangan lain yang dihadapi adalah masih lemahnya keterkaitan antar industri, yaitu antara industri hulu dan hilir maupun antara industri besar dengan industri kecil dan menengah, adanya keterbatasan berproduksi barang setengah jadi dan komponen di dalam negeri, keterbatasan industri berteknologi tinggi, kesenjangan kemampuan ekonomi antardaerah, serta ketergantungan ekspor pada beberapa komoditas tertentu. Sektor industri khususnya Industri Besar dan Sedang (IBS) berperan cukup besar mendorong pertumbuhan ekonomi Yogyakarta (Pemerintah Provinsi Daerah Istimewa Yogyakarta, 2015).

Sektor industri tidak hanya berperan memberikan kontribusi ekonomi yang besar melalui nilai tambah, kesempatan kerja, serta devisa namun sektor ini dapat menunjang daya saing suatu wilayah. Sifat industri ini yang cenderung padat modal dan teknologi berpeluang membentuk nilai tambah yang besar dengan pertumbuhan yang tinggi pula. Sektor industri pengolahan menyerap tenaga kerja paling besar dibandingkan sektor lainnya. Ke depan, sektor industri pengolahan masih perlu berkembang lagi sehingga mampu menyerap angkatan kerja baru dan menyerap tenaga kerja yang menumpuk di sektor pertanian dan bangunan yang kurang produktif (Pemerintah Provinsi Daerah Istimewa Yogyakarta, 2015). Efek ganda penciptaan lapangan kerja dari industrialisasi berdampak positif pada masyarakat, dimana setiap pekerjaan di sektor manufaktur menciptakan 2,2 pekerjaan di sektor lain (United Nation, 2015).

Kawasan Industri (KI) bertujuan untuk mengendalikan tata ruang, meningkatkan upaya industri yang berwawasan lingkungan, mempercepat pertumbuhan industri di daerah, meningkatkan daya saing industri, meningkatkan daya saing investasi, serta memberikan kepastian lokasi dalam perencanaan dan pembangunan infrastruktur yang terkoordinasi antar sektor terkait. Permintaan lahan kawasan industri terus meningkat seiring dengan program hilirisasi industri dan meningkatnya kinerja perekonomian Indonesia (Pemerintah Provinsi Daerah Istimewa Yogyakarta, 2015).

ABG merupakan kependekan dari AcademicBusiness-Governement yang merupakan bagian dari implementasi konsep Triple Helix di Indonesia. Konsep ini digunakan untuk menciptakan sinergi yang dinamis, kondusif, dan suportif terhadap lingkungan bisnis di suatu negara/wilayah. Namun dalam penerapannya, Indonesia masih menemui banyak kendala. Tantangan banyak dihadapi di daerah Indonesia diluar Pulau Jawa yang masih memiliki keterbatasan terhadap berbagai akses dikarenakan kurangnya komunikasi dan perhatian dari pihak-pihak terkait (Irawati, 2006). Bangun dan Sukarya (2012) dalam penelitiannya menjabarkan karakteristik dan skill yang dibutuhkan agar interkoneksi ABG ini dapat berjalan sukses.

Artikel ini memuat perancangan konsep kawasan industry berbasis potensi daerah (Domestic Based Industry/ DBI) menggunakan pendekatan sinergi academic-business-government $(A B G)$ di Provinsi DIY. Dua daerah diambil untuk memfokuskan penelitian yang berbasis bahan baku lokal ini. Kabupaten Gunung Kidul dengan bahan baku lokal ziolit alam dan Kabupaten Sleman dengan bahan baku lokal salak pondoh dan biogas. Konsep kawasan industri pengolahan yang terbentuk saling terintegrasi satu sama lain.

\section{Metode Penelitian}

Metode perancangan konsep kawasan industri ini dimulai dari tinjauan pustaka, observasi lapangan, dan wawancara dengan pihak-pihak terkait. Hasil tinjauan tersebut dirumuskan dalam bentuk rencana kebijakan dan gambaran skema jejaring rancangan kawasan industri baru di Provinsi DIY. 


\section{Teknik, 37 (2), 2017, 90}

\subsection{Salak pondoh kabupaten sleman}

Salak Pondoh (Salacca zalacca) merupakan buah yang memiliki tingkat produksi tertinggi di Provinsi DIY. Produksi salak tahun 2015 sebesar 73,283 ton yang sebagian besar dihasilkan di Kabupaten Sleman mencapai 71,705 ton atau $97,85 \%$, dan Kabupaten Kulonprogo 1,572 ton atau 2,15\%. (Badan Pusat Statistik Daerah Istimewa Yogyakarta, 2015).

Saat ini petani salak pondoh banyak mengalami kerugian karena penuruanan harga buah salak yang sangat besar. Penyebabnya adalah petani salak pondoh yang terlampau banyak dengan jumlah konsumen yang tetap. Selain itu karena buah salak pondoh bukan termasuk buah yang dapat bertahan lama sehingga salak ini hanya dapat dikirim pada jarak dekat (Putranti, 2015).

Studi analisis ekonomi rumah tangga tani salak pondoh sudah dilakukan di salah satu desa di Kecamatan Turi Kabupaten Sleman. Hasilnya adalah petani salak pondoh di Desa Donokerto yang dulu mengandalkan salak pondoh sebagai sumber pendapatan yang utama, kini lebih mengandalkan kegiatan luar usahatani sebagai sumber pendapatan yang utama. Selain karena rendahnya produktivitas salak pondoh, harga jual yang rendah juga mendorong petani untuk lebih mengembangkan kegiatan di luar pertanian. (Weni, 2015)

Beberapa penelitian untuk memanfaatkan dan meningkatkan nilai ekonomis dari salak pondoh telah banyak dilakukan dan dapat menjadi alternatif dalam mengatasi permasalahan rendahnya nilai jual buah salak saat musim panen. Produk penelitian terkait pemanfaatan salak pondoh diantaranya: respirasi buah salak (Tranggono, Santoso, 1992), pelapis nano komposit salak pondoh(Lin, Zhao, 2007), sintesis carboxy methyl cellulose (CMC) (Setiyoko, 2016), hidrolisis biji salak untuk membentuk monosakarida (Fathoni, 2014), sintesis silika gel (Ahmad, 2012), substrat nata de salacca (Pratiwi et al., 2015), sebagai packing bed untuk filter $\mathrm{H}_{2} \mathrm{~S}$ pada biogas (Lestari et al., 2016).

\subsection{Zeolit alam Kabupaten Gunungkidul}

Salah satu zeolit alam di Indonesia yang memiliki deposit cukup besar dan konsentrasi kandungan zeolit sekitar 60\% adalah zeolit lokal Gunungkidul Yogyakarta dengan jumlah deposit sebesar 55.000.000 $\mathrm{m}^{3}$. Bahan galian ini banyak dijumpai di wilayah perbukitan Baturagung, yaitu di Desa Hargomulyo, Watugajah, Mertelu, dan Tegalrejo di Kecamatan Gedangsari dan di Desa Tancep Kecamatan Ngawen. (Pemerintah kabupaten Gunungkidul, 2015).

Banyak penelitian dilakukan terkait dengan pemanfaatan dan produksi produk bernilai tambah dari zeolit. Hasil-hasil penelitian ini dapat menjadi dasar kelayakan untuk membangun kawasan industri pengolahan zeolit di Gunungkidul. Hasil penelitian tersebut diantaranya: mediacoating slow release fertilizer $(S R F)$ (Styana, 2010; Rosadi, 2010; Subandriyo, 2014;
Suwardi, 2009; Asyari, 2009; Bimantio, 2013; Alisyahbana, 2013), zeolit sebagai adsorben limbah (Setyowati, 2008) dan logam berat seperti cadmium $\left(\mathrm{Cd}^{2+}\right)$ (Bakara, 2016), kobalt (Co(II)) (Widhastu, 2016), tembaga $(\mathrm{Cu}(\mathrm{II}))$ (Romadhonni, 2015), timbal $(\mathrm{Pb}(\mathrm{II}))$ (Munandar, 2014), seng (Zn(II)) (Adlin, 2014), besi (Fe(II)) (Qibthiyah, 2015), dan kromium (Cr) (Amelia, 2016), high grade adsorbent untuk pemurnian produk industri seperti etanol (Rambe, 2010), biodiesel (Furqon, Prasetya, Wilopo, 2013), dan biogas (Sanyoto, 2011).

\subsection{Biogas Kabupaten Sleman}

Sapi potong merupakan salah satu potensi unggulan daerah di Kabupaten Sleman dengan jumlah populasi mencapai 55.000 ekor (Pemerintah kabupaten Sleman, 2016). Pengelolaan limbah peternakan sapi yang selama ini umum dilakukan adalah pemanfaatan langsung sebagai pupuk yang sering disebut pupuk kandang. Salah satu usaha yang dilakukan untuk meningkatkan nilai tambah dari kotoran sapi adalah dengan memanfaatkannya sebagai bahan baku pembuatan biogas dimana telah terdapat lebih dari 200 unit instalasi biogas di Kabupaten Sleman.

Biogas sudah cukup dikenal dimasyarakat, mengenai manfaat dari biogas, namun disamping mengeluarkan gas bio yang dapat dipakai sebagai bahan bakar, dalam instalasi pembuatan biogas dihasilkan pula sludge dalam bentuk campuran padat dan cair yang biasanya dipakai sebagai bahan pupuk organik. Selain dipakai untuk pupuk, penelitian lain menunjukkan bahwa sludge biogas dapat digunakan sebagai media pembawa jamur Trichoderma harzianum yang memiliki manfaat dapat sebagai agen hayati dan stimulator petumbuhan tanaman, sebagai biofungisida beberapa jamur yang berada di lahan pertanian, diantaranya Fusarium oxysporum (Budyanto, 2013). Sludge cair juga dapat digunakan sebagai media biakan alternatif untuk menumbuhkan bakteri Pseudomonas fluorescens yang dapat digunakan sebagai bioprotektan pada tanaman (Chamidah, 2013).

\section{Hasil dan Pembahasan}

Pengembangan potensi salak pondoh sebagai bahan baku industri termasuk dalam salah satu rencana pembangunan jangka panjang Kabupaten Sleman tahun 2006-2025 sesuai dengan Perda Kabupaten Sleman Nomor 7 Tahun 2005 dengan meningkatkan pembangunan industri yang diarahkan sebanyak mungkin memanfaatkan dan mengolah bahan lokal dari hasil pertanian dan industri yang manghasilkan input bagi proses produksi pertanian, serta rekayasa mesin/alat tepat guna dalam rangka menghasilkan produk unggulan baik untuk memenuhi kebutuhan dalam negeri maupun ekspor (Pemerintah kabupaten Sleman, 2005) dan merupakan bagian peningkatan nilai tambah sumber daya alam sesuai dengan Pasal 31 dan 32 Undang-Undang (UU) Nomor 3 


\section{Teknik, 37 (2), 2017, 91}

Tahun 2014 Tentang Perindustrian (Kementerian Perindustrian, 2014).

Salah satu solusi agar pasar salak pondoh menjadi lebih luas adalah dengan mengolahnya lebih lanjut sehingga dapat menjadi lebih bernilai dan dapat disimpan lebih lama. Pemerintah harus dapat melihat potensi ini dengan membuat Pusat Pengolahan Salak Pondoh, sehingga petani dapat terbantu karena dengan adanya pusat pengolahan ini permintaan pasar akan meningkat. Pusat pengolahan dalam hal ini adalah industri yang mengolah salak pondoh menjadi produk dengan tingkat ekonomi yang lebih tinggi. Pusat Pengolahan Salak Pondoh ini dapat mengambil lokasi di lahan Agrowisata Turi, Sleman.

Pemerintah dapat memberikan andil dengan menciptakan situasi usaha yang kondusif dan pro-rakyat, sehingga bisnis industri pengolahan salak pondoh ini dapat dirintis dan berkembang. Langkah konkret yang dapat diambil antara lain: penetapan taxholiday, pembuatan undang-undang agar pelaku usaha turunan diwajibkan menggunakan bahan baku utama/pendukung produksi lokal terlebih dahulu, sesuai dengan Pasal 85 Undang-Undang Nomor 3 Tahun 2014 Tentang Perindustrian (Kementerian Perindustrian, 2014), dan memberdayakan KUD sebagai agen pemasaran produkproduk olahan turunan salak pondoh yang memang bersumber dari desa-desa di Provinsi DIY.

Dasar pembentukan industri pengolahan zeolit harus berlokasi mendekati bahan baku, karena proses awal dalam memproduksi olahan zeolit ini membutuhan alat dan media angkut yang besar. Hal ini menjadi tidak ekonomis bila lokasi Industri tidak berada di daerah Gunungkidul.

Sisi positif dari pemilihan lokasi ini adalah peningkatan ekonomi warga Gunungkidul yang dapat bekerja pada Industri ini dan dibantu oleh peraturan pemerintah dalam hal ini Dinas Tenaga Kerja untuk membuat kewajiban bagi industri di Gunungkidul untuk memprioritaskan pemenuhan tenaga kerja yang berasal dari SDM lokal.

Industri pengolahan zeolit ini mendapat dukungan dari pemerintah dengan terbitnya Peraturan Menteri Perdagangan RI Nomor 119 tentang ketentuan ekspor produk pertambangan hasil pengolahan dan pemurnian, dimana zeolit dalam bentuk bubuk dengan kapasitas tukar kation < 80 meq/100 gram termasuk dalam produk pertambangan yang dilarang ekspornya (Menteri Perdagangan Republik Indonesia, 2015). Sehingga keberadaan industri pengolahan ini menjadi semakin dibutuhkan baik dari segi nilai tambah produk maupun untuk peningkatan kesejahteraan warga lokal.

Agar menggiatkan pertumbuhan bisnis, pemerintah dapat menerapkan kebijakan tax holiday untuk industri pengolahan zeolit ini karena potensi nilai tambahnya yang tinggi dan dengan adanya industri olahan ini maka keanekaragaman industri turunan dapat terpenuhi, pembuatan undang-undang agar pelaku usaha turunan diwajibkan menggunakan bahan baku utama/pendukung produksi lokal terlebih dahulu, sesuai dengan Pasal 85 Undang-Undang (UU) Nomor 3 Tahun 2014 Tentang Perindustrian (Kementerian Perindustrian, 2014). Dari segi pemasaran produk, pemerintah dapat memanfaatkan KUD sebagai penghubung distribusi produk utama agar pemenuhan kebutuhan dalam provinsi dapat terpenuhi terlebih dahulu sebelum melangkah kepada penjualan ke luar daerah.

Pihak akademik dapat berperan sebagai think-tank dan bagian pengembangan baik untuk kualitas produk maupun bahan baku, dimana zeolit merupakan salah satu bidang penelitian yang cukup sering ditinjau. Data dari Perpustakaan UGM menunjukkan untuk tahun 2016 saja sudah terdapat 36 judul penelitian terkait dengan zeolit.

Sementra untuk industri pengolahan biogas dapat dijadikan suatu konsep kawasan eduwisata energi terbarukan. Pemerintah dapat mengembangkan konsep ini dengan bekerjasama dengan pihak akademik sebagai mentor untuk pelatihan dan pembinaan kepada warga sekitar area biogas ini agar dapat mengelola kawasan eduwisata yang akan memberikan dampak yang signifikan terhadap ketahanan ekonomi wilayah, karena telah meningkatkan pendapatan ekonomi dan membuka berbagai jenis usaha baru bagi warga sekitar. Hal ini dapat dikatakan sebagai wujud dari ketahanan ekonomi keluarga yang merupakan dasar dari ketahanan ekonomi wilayah. Seperti kerjasama yang telah dilakukan antara PUSTEK UGM dengan Karang Taruna Desa Poncosari Kabupaten Bantul (Yusuf et al., 2015).

Rancangan sistem industri ini harus dapat saling terkait/terintegrasi satu sama lain, baik dengan industri rancangan baru maupun dengan industri yang sudah ada di Provinsi DIY. Hal ini dalam rangka meningkatkan daya saing dan nilai jual dari potensi lokal daerah dan menggiatkan usaha bisnis berbasis bahan baku lokal yang akan menyerap banyak tenaga kerja lokal pula, sehingga diharapkan perputaran ekonomi akan berjalan dan peningkatan kesejahteraan warga Provinsi DIY dapat meningkat. Sistem jejaraing dari konsep kawasan industri baru di DIY dapat dilihat pada gambar 1 .

Sinergi yang dapat dibangun antara dosen, mahasiswa, pemerintah, dan masyarakat petani salak pondoh di Provinsi DIY sangat diperlukan dalam mengoptimalkan potensi sumber daya alam maupun manusia yang ada di wilayah tersebut, sesuai dengan Pasal 42a Undang-Undang Nomor 3 Tahun 2014 Tentang Perindustrian (Kementerian Perindustrian, 2014).

Peran pemerintah sebagai regulator harus dapat mengintegrasi/mensintesis secara holistik semua kepentingan yang dimiliki oleh pelaku bisnis, akademik, dan pemerintah itu sendiri, sehingga program dan aturan yang dibuat dapat mengayomi seluruh pihak namun tidak tumpang tindih diantaranya. 


\section{Teknik, 37 (2), 2017, 92}

\section{Kesimpulan}

Konsep ABG dapat diterapkan sebagai dasar dalam merancang kawasan industri baru di Provinsi DIY yang bahan bakunya berbasis dari sumberdaya lokal di Kabupaten Sleman dan Gunungkidul. Konsep ini dapat mengeliminir program-program pemangku kepentingan yang sebelumnya berdiri sendiri-sendiri dan saling tumpang tindih menjadi satu kesatuan yang terintegrasi dan memberikan dampak positif pada ekonomi kerakyatan. Dalam jangka panjang, hal ini dapat memberikan peningkatan yang positif pula pada nilai PDRB Provinsi DIY.

Konsep ini masih dapat ditingkatkan atau diperluas ruang lingkupnya dengan memasukkan potensi lain yang ada di semua kabupaten/kota di Provinsi DIY, tidak hanya di Kabupaten Sleman atau Gunungkidul.

\section{Daftar Pustaka}

Adlin, N. (2014). Zeolit Termodifikasi Magnetit Berbasis Metode Kopresipitasi Sebagai Adsorben Zn(II). Skripsi. Universitas Gadjah MadaYogyakarta.

Ahmad, M. (2012). Sintesis Silika Gel Dari Pelepah Pohon Salak Pondoh Menggunakan Natrium Hidroksida Dan Asam Sulfat. Skripsi. UIN Sunan Kalijaga Yogyakarta.

Alisyahbana, D. (2013). Pemanfaatan Zeolit Sebagai Pengikat Pupuk Urea. Thesis. Universitas Gadjah Mada Yogyakarta.

Amelia, F. (2016). Kajian Desorpsi Kromium Total Menggunakan Asam Tartarat Pada Tanah Sekitar Industri Penyamakan Kulit Hewan Di Yogyakarta. Skripsi. Universitas Gadjah MadaYogyakarta.

Asyari, M. (2009). Penelitian Awal Granulasi Pupuk Kandang,Pupuk Anorganik, dan Zeolit sebagai Slow Release Fertilizer. Skripsi. Universitas Gadjah MadaYogyakarta.

Badan Pusat Statistik Daerah Istimewa Yogyakarta. (2015). Statistik Hortikultura Daerah Istimewa Yogyakarta. Badan Pusat Statistik Provinsi Daerah Istimewa Yogyakarta.

Badan Pusat Statistik Daerah Istimewa Yogyakarta. (2016). Statistik Daerah Daerah Istimewa Yogyakarta 2016. Badan Pusat Statistik Daerah Istimewa Yogyakarta.

Bakara, T. M. (2016). Sintesis Komposit Zeolit Magnetit Sebagai Adsorben Cepat Pisah Ion Cd2+. Skripsi. Universitas Gadjah MadaYogyakarta.

Bangun, Y. R., Sukarya, F. R. (2012). Calling for ABG (Academic-Business-Government) Leadership Early Identification of Effective Characteristics of Leadership to Support Triple Helix Model. Procedia - Social and Behavioral Sciences, 52, 187-196.

Bimantio, M. P. (2013). Pengaruh Ukuran Butir dan Waktu Aktivasi Zeolit Alam Terhadap Adsorpsi
Dan Desorpsi $\mathrm{NH}_{4} \mathrm{OH}$ dan $\mathrm{KCl}$ Sebagai Model Pupuk - Zeolit Alam. Skripsi. Universitas Gadjah MadaYogyakarta.

Budyanto, E. C. (2013). Pembuatan Pupuk Organik Dengan Memanfaatkan Sludge Pembuatan Biogas Sebagai Media Pembawa Trichoderma harzianum. Thesis. Universitas Gadjah Mada Yogyakarta.

Chamidah, N. (2013). Pupuk Cair dari Sludge Cair Hasil Samping Biogas Kotoran Sapi Yang Diperkaya Bioprotektan Pseodomonas Fluorescens : Pembuatan dan Uji Efektifitasnya. Thesis. Universitas Gadjah Mada Yogyakarta.

Fathoni, F. (2014). Studi Potensi Biji Salak (Salacca Edulis Reinw) Sebagai Sumber Alternatif Monosakarida Dengan Cara Hidrolisis Menggunakan Asam Klorida. Skripsi. Universitas Gadjah MadaYogyakarta.

Furqon, M. H., Prasetya, A., Wilopo, W. (2013). Pemanfaatan Zeolit Diaktifkan Dengan Larutan Asam Untuk Pemurnian Biodiesel. ASEAN Journal of Systems Engineering, 1(1), 32-35.

Irawati, D. (2006). Understanding The Triple Helix Model from The Perspective of a Developing Country: A Demand or A Challenge for Indonesian. International Conference Triple Helix Paradigm for Development: Strategies for CoOperation and Exchange of Good Practice. Bristol: Bristol Business School.

Kementerian Perindustrian. (2014). Undang-Undang Republik Indonesia Nomor 3 Tahun 2014 Tentang Perindustrian. Indonesia.

Lestari, R. A., Sediawan, W. B., Syamsiah, S., Sarto, \& Teixeira, J. A. (2016). Hydrogen sulfide removal from biogas using a salak fruit seeds packed bed reactor with sulfur oxidizing bacteria as biofilm. Journal of Environmental Chemical Engineering, 4, 2370-2377.

Lin, D., Zhao, Y. (2007). Innovation in the development and application of edible coating for fresh and minimally processed fruits and vegetables. Food Science and Food Safety, 6, 60-75.

Menteri Perdagangan Republik Indonesia. (2015). Peraturan Menteri Perdagangan Republik Indonesia Nomor 119/M-Dag/PER/12/2015 Tentang Ketentuan Ekspor Produk Pertambangan Hasil Pengolahan dan Pemurnian.Kementerian Perdagangan Republik Indonesia.

Munandar, A. (2014). Adsorpsi Logam Pb Dan Fe Dengan Zeolit Alam Teraktivasi Asam Sulfat. Skripsi. UIN Sunan Kalijaga Yogyakarta.

Pemerintah kabupaten Gunungkidul. (2015). Kondisi Umum. Tersedia di http://www.gunungkidulkab.go.id/D74db63a914e6fb0f4445120c6fa44e6a-NR-1000.html. Diakses 18 Februari 2017. 


\section{Teknik, 37 (2), 2017, 93}

Pemerintah kabupaten Sleman. (2005). Peraturan Daerah Kabupaten Sleman Nomor 7 Tahun 2005 Tentang Rencana Pembangunan Jangka Panjang Kabupaten Sleman Tahun 2006-2025. Pemerintah Kabupaten Sleman.

Pemerintah kabupaten Sleman. (2016, April 5). Potensi Unggulan Daerah. Tersedia di http://www.slemankab.go.id/3275/potensiunggulan-daerah.slm. Diakses 18 Februari 2017.

Pemerintah Provinsi Daerah Istimewa Yogyakarta. (2015). Seri Analisis Pembangunan Wilayah Provinsi Daerah IstimewaYogyakarta 2015.Bappenas Yogyakarta.

Pratiwi, R., Lestari, F.B., Widianto, D. (2015). Pemanfaatan Limbah Buah Salak Pondoh Sebagai Substrat Nata De Salacca Melalui Aplikasi Bioteknologi di Dusun Tegal Domban, Sleman,Yogyakarta. Indonesian Journal of Community Engagement, 1(1), 39-52.

Putranti, F. S. (2015). Pusat Pengolahan Salak Pondoh Turi, Sleman dengan Pendekatan Kontekstual Lingkungan. Skripsi. Universitas Gadjah MadaYogyakarta.

Qibthiyah, M. (2015). Studi Penurunan Kadar Logam Besi (Fe) Dan Kobalt (Co) Pada Limbah Cair Industri $\mathrm{Cv}$ Batik Indah Raradjonggrang Yogyakarta Dengan Sistem Penyaring Elektromagnetik. Skripsi. Universitas Gadjah MadaYogyakarta.

Rambe, L. S. (2010). Pembuatan etanol kering (anhydrous ethanol) dengan memanfaatkan zeolit alam sebagai adsorben.Thesis. Universitas Gadjah MadaYogyakarta.

Romadhonni, T. (2015). Zeolit-APTMS Tercetak Cu Sebagai Adsorben $\mathrm{Cu}(\mathrm{II})$ Dalam Air. Thesis. Universitas Gadjah MadaYogyakarta.

Rosadi, I. (2010). Studi pemanfaatan zeolit dan bentonit sebagai coating pada pembuatan pupuk granul slow release fertilizer. Thesis. Universitas Gadjah MadaYogyakarta.

Sanyoto, A. T. (2011). Adsorbsi Gas Pengotor Pada Biogas Dengan Menggunakan Campuran Zeolit Dan Karbon Aktif. Thesis. Universitas Gadjah MadaYogyakarta.
Sarengat, N., Yuniari, A., Setyorini, I., Suyatini. (2015). Kajian Potensi Pencemaran Industri Pada Lingkungan Perairan Di Daerah Istimewa Yogyakarta. Seminar Nasional Kulit, Karet, dan Plastik.Balai Besar Kulit, Karet dan Plastik Yogyakarta .

Setiyoko, A. (2016). Sintesis dan Karakterisasi Carboxy Methyl Cellulose (CMC) Dari Biji Salak (Salacca edulis Reinw) Pondoh Super. Thesis. Universitas Gadjah MadaYogyakarta.

Setyowati, E. (2008). Studi Fisis Pengaruh Kuat Arus, Jenis Polutan Logam dan Waktu Pengambilan Output Penyaringan terhadap Efektivitas Penyaring Elektromagnetik. Skripsi. Universitas Gadjah MadaYogyakarta.

Styana, U. F. (2010). Penggunaan metode coating campuran zeolit dan pati untuk meningkatkan ketertarikan nitrogen dan kekuatan pada pupuk granul. Thesis. Universitas Gadjah MadaYogyakarta.

Subandriyo, E. (2014). Pembuatan Pupuk Urea Lepas Lambat Dengan Proses Pelapisan Urea Asetaldehid Dan Zeolit. Thesis. Universitas Gadjah MadaYogyakarta.

Suwardi. (2009). Teknik Aplikasi Zeolit Di Bidang Pertanian Sebagai Bahan Pembenah Tanah. Jurnal Zeolit Indonesia, 8(1), 32-38.

Tranggono, S., Santoso, U. (1992). Memperpanjang Umur Simpan Buah Salak Pondoh dengan Penyimpanan dalam Atmosfir Termodifikasi. Thesis. Universitas Gadjah MadaYogyakarta.

United Nation.s (2015). Lembar Fakta SDGs Indonesia. Indonesia. Jakarta: United Nations

Weni, N. H. (2015). Analisis Ekonomi Rumah Tangga Tani Salak Pondoh di Desa Donokerto Kecamatan Turi Kabupaten Sleman. Skripsi. Universitas Gadjah MadaYogyakarta.

Widhastu, K. (2016). Sintesis Komposit Zeolit-Magnetit Sebagai Adsorben Ion Logam Co(II). Skripsi. Universitas Gadjah MadaYogyakarta.

Yusuf, I. F., Martono, E., Prasetya, A. (2015). Peran Pemuda Dalam Pengembangan Eduwisata Energi Terbarukan Dan Implikasinya Terhadap Ketahanan Ekonomi Wilayah (Studi di Desa Poncosari Kecamatan Srandakan Kabupaten Bantul Daerah Istimewa Yogyakarta). Jurnal Ketahanan Nasional, 285-305 


\section{$\overline{\overline{\underline{\underline{\underline{E K N V K K}}}}}$}

Available online at: http://ejournal.undip.ac.id/index.php/teknik

Teknik, 38 (2), 2017, 113-118

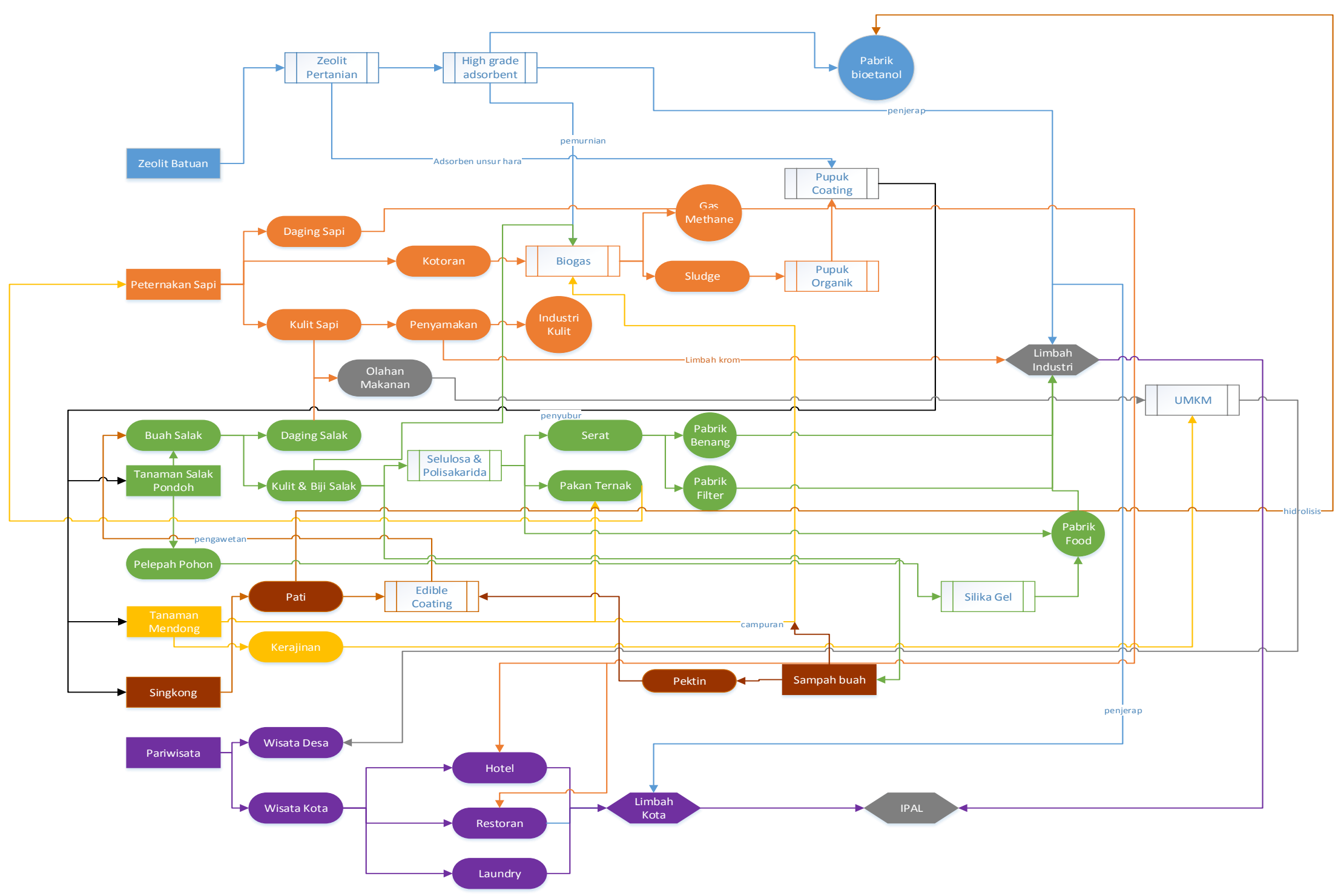

Gambar 1. Skema Jejaring Rancangan Kawasan Industri Baru Provinsi DIY 